\title{
The Development of Mobile Client Application in Yogyakarta Tourism and Culinary Information System Based on Social Media Integration
}

\author{
Novrian Fajar Hidayat \\ Department of Electrical Engineering and Information \\ Technology \\ Universitas Gadjah Mada \\ Yogyakarta, Indonesia
}

\author{
Ridi Ferdiana \\ Department of Electrical Engineering and Information \\ Technology \\ Universitas Gadjah Mada \\ Yogyakarta, Indonesia
}

\begin{abstract}
Social network is currently being an important part of someone. Many of users in social network make it an effective publication. One of many things that can be published on social network is tourism. Indonesia has a lot of tourism and culinary, especially on Special District of Yogyakarta.Tourism and culinary resources on Yogyakarta can be published and shared using social network. In addition, development of mobile technology and smartphone make easier to access social network through internet.

The release of Windows Phone 7 makes new color in the world of smartphone. Windows Phone 7comes with elegant interface, Metro Style. Besides that, standardized specification makes Windows Phone 7 suitable for integrating social network with tourism and culinary on Special District of Yogyakarta.

This Research is expected to integrate social network with tourism and culinary on Yogyakarta. The method in this research is using ICONIX method. This method is one method that combines waterfall and agile methods. The results of this study are in the form of applications that run on Windows Phone 7 and consume a web service. This application provides information especially for tourist in order to be able to easily find culinary and tourism in Yogyakarta.
\end{abstract}

Keywords- Social Network; Information Service; Culinary; Tourism; Windows Phone 7.

\section{INTRODUCTION}

Nowadays, 200 milion users login daily into Facebook. In the same time, 95 milion tweets are written[11]. This fact are prove of many users of social network. These resource are on the social network to take the advantage especialy for tourism.

Special District of Yogyakarta, known as region that have a lot of tourism resource. In other side, the development of technology makes internet gives many varies of information. Social network also become important and give contribution for information on internet.

Mobile Client Application provides application service on mobile devices. It is different with web client application, Mobile Client Application could use device specific features such as GPS, camera, and sensors.

One of a smartphone that use mobile client application model is Windows Phone 7. IDC said that Windows Phone 7 would have good sales potential after Nokia introduced the product that using Windows Phone 7 operating system. It would get 20\% market of smartphone [7]. Furthermore, Developing Windows Phone 7 application still has huge potential market since the market application is not huge as Android or iPhone.

Another advantages of developing Windows Phone 7 based aplication are developer no need to worry about the compatibility from one to another device. Windows Phone 7 have standardized hardware specification in order to execute to different device. With Windows Phone 7, integrated application between tourism and social network on Special District of Yogyakarta could be developed. Furthermore, users could share infomation on their social network about tourism or culinary that they liked.

\section{BASIC THEORY AND LITERATURE}

\section{A. Basic Theory}

\section{1) Social Network}

Social Network sites like Facebook or Myspace are network with many users could add detail profile, so they could communicate with others [8]. Social Network is part of social media that focusing in sharing contents or activities. Nowadays, 200 million users login to Facebook every day and in the same time, 95 tweets written every day. Half of the users using mobile device to do it [11].Therefore, the connection any system with social network shall help the application to get the benefit in social media.

\section{2) Tourism Information System}

Tourist Information System is a service that provided by an organization for giving information to tourist about attraction, events, or culinary. It could be web or mobile client. Users could use it for tourism information guide when visiting a point of interest [5].

\section{3) Mobile Client Application}

Mobile Client defined by Darren Ince[3] is a client that not only on one position: in example, a portable computer using mobile phone to communicate with server or a mobile phone use wireless application protocol to connect on web server. Mobile client application runs on client side to provide the rich 
experience to the client through the benefit of the existing mobile application platform.

\section{4) Windows Phone 7}

Microsoft with project codenamed 'Metro' on February 2010 to make new mobile operating system [6]. This operating system known as Windows Phone 7. It adopted Metro interface that different with former Windows Mobile and also another smartphone like Android or Apple iPhone. Windows Phone UI focuses in simplicity and consistency of user experience.

\section{B. Previous Researches}

Kurniawan [10] researched about Mobile Client Application and tourism in Yogyakarta with developing application based on J2ME. This research use RSS 2.0 for providing information into mobile device. It provides read only information about tourism.

Another research about tourism and culinary information service on Yogyakarta also already been done in mobile web platform. It is used mobile web application to displaying information on mobile device [9]. This research already uses social network and flexible user interface.

The former research used Android Smartphone to running an application that provides user information about tourism and culinary [1]. This application also could access GPS and share to social network. This application named 'JOGJANAN'. Based on the previous researches, Table II shows the differentiation between this application with the previous researcher

TABLE I. COMPARISON WITH SIMILAR APPLICATION

\begin{tabular}{|c|c|c|}
\hline Author & Platform & Benefits \\
\hline Arfian, 2010 & Mobile Web & $\begin{array}{c}\text { Adaptive web can be } \\
\text { used in various mobile } \\
\text { devicesbased on HTML } \\
\text { and CSS standard }\end{array}$ \\
\hline $\begin{array}{c}\text { Kurniawan, } \\
2010\end{array}$ & J2ME Client & $\begin{array}{c}\text { Focusing in fast and } \\
\text { lightweight application } \\
\text { based on RSS } \\
\text { technology }\end{array}$ \\
\hline Febriyanto, 2011 & Android & $\begin{array}{c}\text { Focusing in smartphone } \\
\text { android platform based } \\
\text { on Web Services } \\
\text { technology }\end{array}$ \\
\hline This Research & Windows Phone & $\begin{array}{c}\text { Focusing in smartphone, } \\
\text { windows phone } \\
\text { platform uses REST and } \\
\text { Social Media }\end{array}$ \\
\hline
\end{tabular}

\section{PREPARERESEARCH METHOD}

When developing this software, researcher adopted ICONIX method. ICONIX method is method that combine classical or waterfall method and agile method [4]. It is start from make use case diagram, domain modeling diagram, robustness diagram, sequence diagram, and the last static class diagram. ICONIX is chosen because the development of Jogjanan mobile application needs lightweight software engineering method. ICONIX is already familiar with the technical team who build the software. Figure 1, shows the ICONIX method approach.

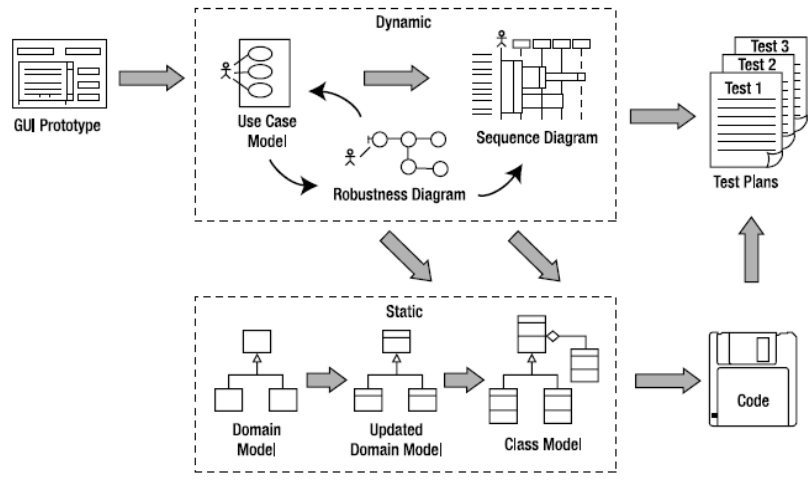

Figure 1. ICONIX Method[4]

\section{RESULTAND REVIEW}

\section{A. Application Architecture}

This application uses MVVM (Model View View Model) design pattern. This design pattern fit to use on an application that implement mark-up language such as XAML.

View is part that directly communicated with user. It is also contain user interface. View Model is the logic part and bridge between View and Model. Model is representing from object data.

In this architecture, researcher added Helper as a component that could not include to Model, View or View Model. Figure 2, shows the application architecture of Jogjanan. It is used layered architecture that is combined with MVVM model.

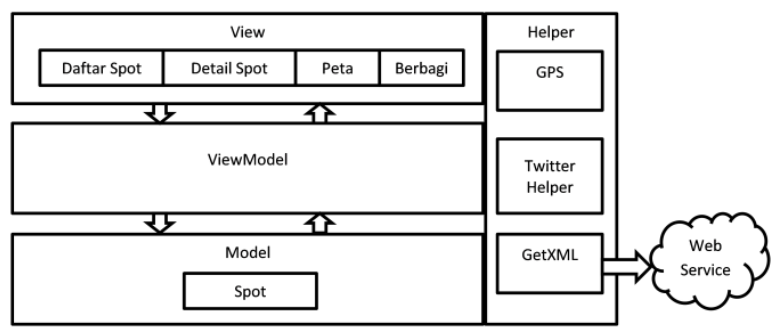

Figure 2. Application Architecture

Above the application architecture, this application connected with system that developed from former research. It had been developed web service as data center for consumed by this application. Figure 3, shows the system architecture of Jogjanan mobile application.

\section{B. Web Service Testing}

This application is a part of tourism and culinary information system that have been developed. Therefore, the web services are already developed by the previous researches [1] [10].

In order to get the data from a server, mobile client has an access to provide web service. Web service is provided through WSDL (web services development language). The web service is developed by PHP and nuSOAP library. 


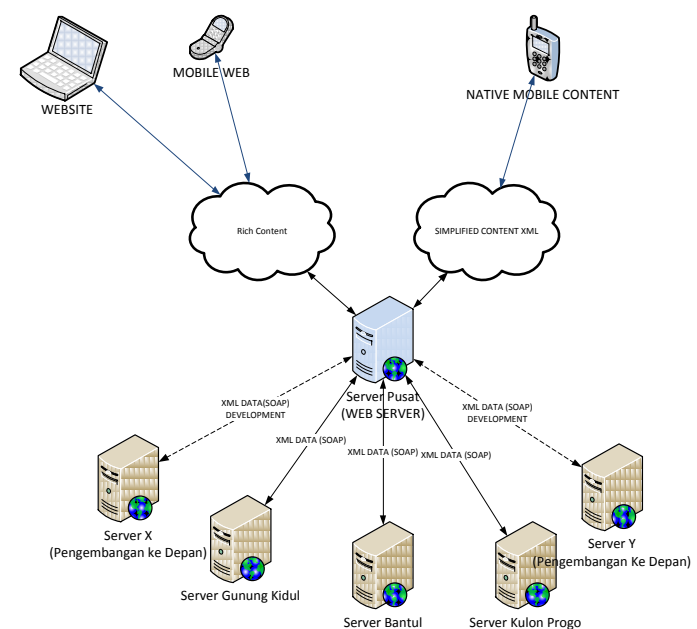

Figure 3. System Architecture [2]

However, during the testing mode, the web services couldn't be connected to Windows Phone. Researcher does several tests and shows that that the WSDL format is not suitable with Windows Phone.

Therefore, the web service is extended by providing a REST result (Representational State Transfer). This web service will give output as XML data. The XML data is consumed through Windows Phone user interface

\section{Spot List Testing}

When application running, user will enter main page, Spot List. This application will call web service that located on Jogjanan service through SOAP Header authentication model. After application got the data, it will displays on the screen as culinary and spot using two ways binding technique. Two ways binding provides side by side binding between client and the web services. Figure 4 shows the binding result in user interface.

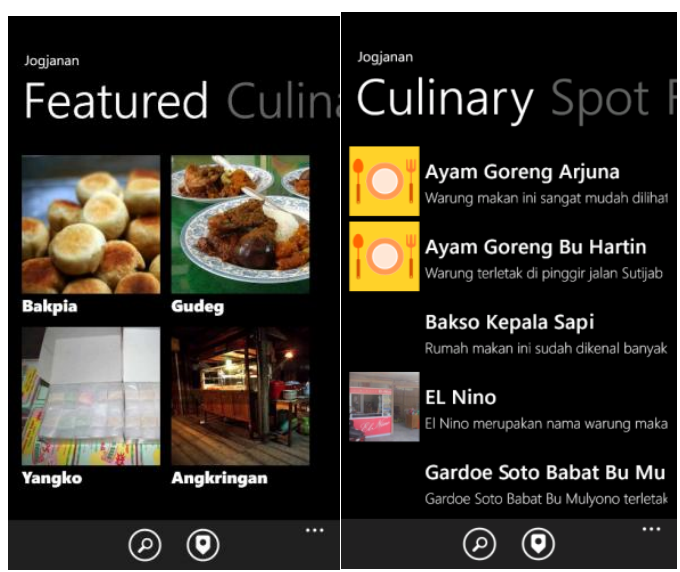

Figure 4. Featured page (left) and Culinary page (right).

\section{Detail Spot Testing}

When user click or tap at a content on the list, the application will navigate to detail spot page.
This page displayed spot name, image thumbnail, spot description, facilities, a button to navigate to map and share button.

This feature uses progressive and scaling image binding to display image in sufficient resolution. Figure 5 shows the spot detail in user interface.

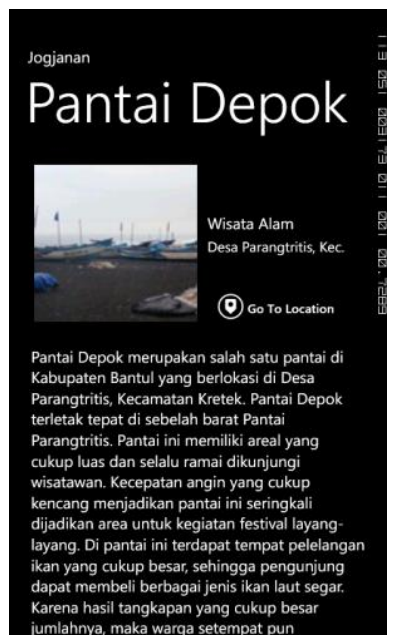

Figure 5. Detail Page

\section{E. Social Network Sharing Testing}

This testing uses twitter as social network for sharing. After tap or click share button on detail spot then user will ask username and twitter password for authentication. Then, the user could write a message that will be published on Twitter. It is automatically include the URL of spot. It will share the nice URL to the user peers in social network. Figure 6 shows the twitter display when share the Jogjanan POI (point of interest).

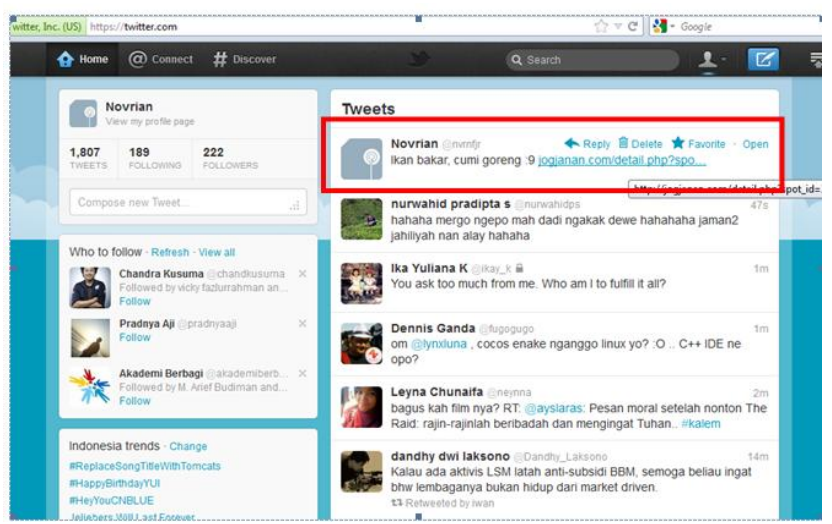

Figure 6. Twitter Display

\section{F. Map Testing}

Map feature could be accessed by tapingthe map icon on Spot list page. Map feature will display the location of tourism and culinary spot. Besidesof that, the map feature display user location by using A-GPS that already integrated in windows Phone devices. This map can zoom in or out as shown in Figure 7. 


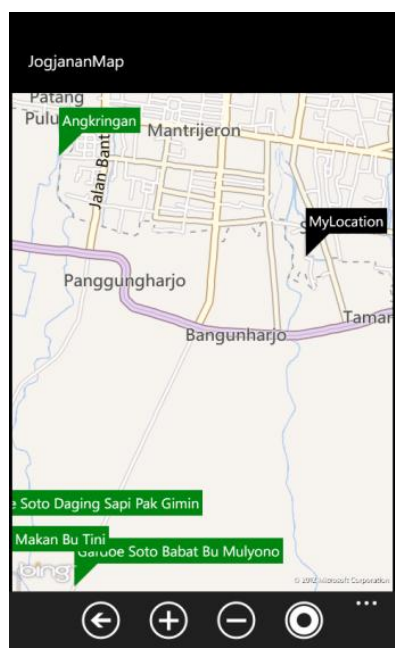

Figure 7. Map Page

\section{G. Marketplace Verification and Validation}

Visual Studio 2010 for developing Windows Phone 7 application provide testing tool in order to check an application. There are four items that are verified on Visual Studio which are packaging format, validation user experience, iconography standard, and application screenshot.

In this test, JogjananPhone application is verified and validated on the Visual Studio Windows Phone Testing kit. Figure 8 shows the Testing toolkit helps validation and verification for market store purpose.

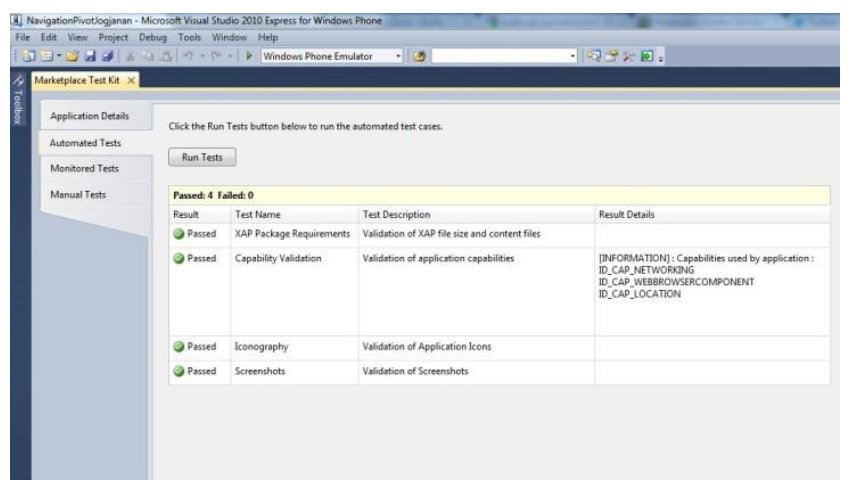

Figure 8. Result of Marketplace Verification and Validation test

\section{H. Comparison with The Existing Application}

TABLE II. COMPARISON WITH SimILAR APPLICATION

\begin{tabular}{|l|l|l|}
\hline \multicolumn{1}{|c|}{ Comparison } & \multicolumn{1}{|c|}{ Toresto } & \multicolumn{1}{c|}{ JogjananPhone } \\
\hline \multicolumn{1}{|c|}{$\begin{array}{c}\text { Application } \\
\text { Focus }\end{array}$} & \multicolumn{1}{|c|}{$\begin{array}{c}\text { Culinary Information } \\
\text { system }\end{array}$} & $\begin{array}{l}\text { Tourism and Culinary } \\
\text { Information System }\end{array}$ \\
\hline $\begin{array}{l}\text { Share to social } \\
\text { network }\end{array}$ & $\begin{array}{l}\text { Share to Facebook } \\
\text { and Twitter }\end{array}$ & $\begin{array}{l}\text { Can share to Facebook and } \\
\text { Twitter }\end{array}$ \\
\hline Tourism object & $\begin{array}{l}\text { Not providing tourism } \\
\text { object }\end{array}$ & $\begin{array}{l}\text { Provide and displaying } \\
\text { tourism object }\end{array}$ \\
\hline Maps & $\begin{array}{l}\text { On the detail culinary } \\
\text { page }\end{array}$ & Different page \\
\hline $\begin{array}{l}\text { Programming } \\
\text { Language }\end{array}$ & Java & .NET \\
\hline Maps Type & Google Map & Bing Map \\
\hline
\end{tabular}

\begin{tabular}{|l|l|l|}
\hline Point of interest & More than 100 POI & 60 POI \\
\hline $\begin{array}{l}\text { Contextual POI } \\
\text { (Nearby) }\end{array}$ & Yes using GPS & Yes using GPS \\
\hline
\end{tabular}

Toresto is similar application that running in Android operating system is already on Google Play since 2011. Toresto focuses in culinary system, meanwhile the Jogjanan focuses in culinary and tourism system. Just like Toresto, Jogjanan also available in others platform such as web, mobile, and rich client.

Table II shows the differentiation between this applications with the existing application that exist in Windows Phone 7 marketplace. By seeing the table, is concluded that both application has a differentiation in term of user experience and functionality.

\section{CONCLUSION AND FUTURE WORKS}

After analyzing, testing, and reviewing, it could concluded that this research provides several conclusion which are.

- The mobile application that is developed in this research provides a good insight that many of mobile application use social media as a tool to increase the attractiveness in the application

- The geo-location, maps, and social media combines the unique values of the mobile application. In this research, it is shown that these items provide a "contextual based experience"

- The mobile application should be more accessible for tourist since the existence of application store. However, it made several testing and deployment application harder

This application is just like others mobile application need to be refined in term of user experience. Therefore, it needs a further research about user experience evaluation for contextual based experience.

Several agenda that can be done in the future also related with the need of the application to evaluate the usage effectiveness with or without social media.

\section{REFERENCE}

[1] A. Febriyanto. 2011. Perancangan Aplikasi Android untuk Layanan Informasi Wisata dan Kuliner Daerah Istimewa Yogyakarta. Yogyakarta: Electrical Engineering and Information Technology, Gadjah Mada University.

[2] A. Saktiaji. 2011. Perancangan Web Service Sebagai Sarana Komunikasi Layanan Informasi Wisata dan Kuliner di Daerah Istimewa Yogyakarta berbasis NuSOAP. Yogyakarta: Jurusan Teknik Elektro dan Teknologi Informasi, Universitas Gadjah Mada.

[3] D. Ince. 2001. A Dictionary of the Internet. http://www.encyclopedia.com. accessed 19 October 2011.

[4] D. Rosenberg,M. Stephens \& M. Collins-Cope. 2005. Agile Development with ICONIX Process: People, Process, and Pragmatism. New York: Apress.

[5] H.Afsarmanesh\&L. M. Camarinha-Matos, 2000. Future SmartOrganizations: A Virtual Tourism Enterprise. International Conference on Web Information System Engineering (WISE’00).

[6] H. Lee\& E.Chuvyrov. 2011. Beginning Windows Phone 7 Development Second Edition. New York: Apress. 
[7] K. Nagamine. 2011. Worldwide Smartphone Market Expected to Grow 55\% in 2011 and Approach Shipments of One Billion in 2015, According to http://www.idc.com/getdoc.jsp?containerId=prUS22871611. accessed 19 October 2011

[8] P.Walden \&C. Carlsson. 2011. Travel Information Search - The Presence of Social Media. Proceedings of the 44th Hawaii International Conference on System Sciences.

[9] R. A.Arfian. 2010. Pengembangan Aplikasi Mobile Web untuk Wisata dan Kuliner Yogyakarta. Yogyakarta: Jurusan Teknik Elektro dan Teknologi Informasi, Fakultas Teknik, UGM.

[10] R. E. Kurniawan. 2010. Perancangan aplikasi Client Mobile Web Service Info Tempat Wisata di Yogyakarta dengan J2ME dan RSS 2.0. Yogyakarta: Jurusan Teknik Informatika, STMIK AMIKOM.
[11] S. Dixon. 2011. Social: Holy Crap Social Media Statistics 2011. http://www.ecademy.com/node.php?id=166989. accessed 19 October 2011.

\section{AUTHORS PROFILE}

Novrian Fajar Hidayat, is an engineer from Universitas Gadjah Mada. $\mathrm{He}$ focuses in User Experience engineer and creative media development. In his daily life he joins Microsoft Innovation Center as a UX Specaialist. He can be reached at thenovrianmail@gmail.com

Ridi is a lecturer and researcher in Universitas Gadjah Mada. He finished doctoral degree in Software Engineering (ALM) focusing in Agile methodology. He has several Microsoft certifications such as MCTS, MCPD, MCITP, and MCT. Nowaday, Ridi's loves to write his tought at blog.ridilabs.net or on his twitter at @ ridife 